\title{
Men's and Women's Style of Living and Motivation to Run in Charity Events
}

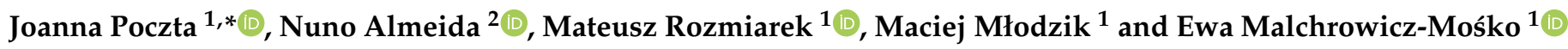 \\ 1 Faculty of Sport Sciences, Poznan University of Physical Education, 61-871 Poznan, Poland; \\ rozmiarek@awf.poznan.pl (M.R.); maciej_mlodzik@wp.pl (M.M.); malchrowicz@awf.poznan.pl (E.M.-M.) \\ 2 CiTUR, School of Tourism and Maritime Technology, Polytechnic of Leiria, 2411-901 Leiria, Portugal; \\ nunoalmeida@ipleiria.pt \\ * Correspondence: jpoczta@awf.poznan.pl
}

Citation: Poczta, J.; Almeida, N.; Rozmiarek, M.; Młodzik, M.;

Malchrowicz-Mośko, E. Men's and Women's Style of Living and Motivation to Run in Charity Events. Sustainability 2021, 13, 5287. https:// doi.org/10.3390/su13095287

Academic Editors: Guillermo Felipe López Sánchez and Lee Smith

Received: 28 February 2021

Accepted: 26 April 2021

Published: 9 May 2021

Publisher's Note: MDPI stays neutral with regard to jurisdictional claims in published maps and institutional affiliations.

Copyright: (c) 2021 by the authors. Licensee MDPI, Basel, Switzerland. This article is an open access article distributed under the terms and conditions of the Creative Commons Attribution (CC BY) license (https:/ / creativecommons.org/licenses/by/ $4.0 /)$.

\begin{abstract}
Running has been very popular for years, especially in organized mass runs. Various running events take place all over the world, at different distances and locations, including charity running events. However, there has not been any research on the social impact of these events on participants to date. This article/paper is an attempt to remedy this situation. The authors conducted their research by the diagnostic survey method using standardized interview technique during the 6th Santa Claus Run organized in Poznan on the day of Santa Claus. A sample of 136 runners: 49 male respondents and 87 female respondents participated in the event voluntarily and completed a questionnaire. Therefore, the main goal of the study was to recognize the relationship between the lifestyles of men and women in the context of participation in a charity running event, in order to evaluate the differences between them. The specific goal was to discern the motives to take part in such kind of an event, as well as to find out what influence the participation in a charity run has on the respondents, both those leading an active and passive lifestyle. The most important result and the only one statistically significant difference in the conducted study was the indication that women have more empathy and participate more often than men in charity runs.
\end{abstract}

Keywords: charity events; charity run; physical activity motivations

\section{Introduction}

Special philanthropic and social sports events are a particularly popular form of physical effort, during which participants collect funds for a given charity goal [1]. Their extremely open and friendly formula in the context of fundraising means that they effectively complement a wide range of other, historically more commonly used forms of marketing tools, such as advertising or direct promotion, as well as modern forms, including telemarketing, billboards or websites [2]. For this reason, they can be included in the group of mechanisms that raise funds for specific and predefined undertakings. The main beneficiaries of financial support are entities that benefit from clearly defined assistance, most often provided by a specialized intermediary organization for this purpose on the basis of the activity performed - for example, a religious community, foundation or association. The latter two are listed as the most popular forms of NGOs, i.e., non-governmental organizations, also known as non-profit organizations [3]. Their activity is not focused on profit, but on fulfilling and satisfying needs. These organizations basically allocate all the obtained income to activities aimed at helping others (because such entities also meet their basic organizational needs, such as creating social campaigns or paying employees' salaries), which inspires general social trust and leads to more and more of them being created over the years [4]. This does not mean that natural persons running a business do not have the possibility to take similar actions-on the contrary, because the universal role of the values resulting from helping others is rapidly expanding to other entities, which, although their statutory goals are different, do not forget about helping initiatives. 
Table 1 presents the state of research over several years in the field of charity sports events.

Table 1. State of The Art.

\begin{tabular}{|c|c|c|c|}
\hline Date & Author/Authors & Title & Journal \\
\hline 1999 & $\begin{array}{l}\text { Bennett R. } \\
\text { Gabriel H. }\end{array}$ & $\begin{array}{l}\text { Charity Involvement and Customer } \\
\text { Preference for Charity Brands }\end{array}$ & Journal of Brand Management \\
\hline 2003 & Webber D. & Understanding charity fundraising events & $\begin{array}{c}\text { International Journal of Nonprofit and } \\
\text { Voluntary Sector Marketing }\end{array}$ \\
\hline 2007 & $\begin{array}{l}\text { Bennett R. } \\
\text { Mousley W. } \\
\text { Kitchin P. } \\
\text { Ali-Choudhury } \\
\text { R. }\end{array}$ & $\begin{array}{l}\text { Motivations for participating in } \\
\text { charity-affiliated sporting events }\end{array}$ & Journal of Customer Behaviour \\
\hline 2009 & $\begin{array}{l}\text { Filo K. } \\
\text { Funk D.C. } \\
\text { O'Brien D. }\end{array}$ & $\begin{array}{c}\text { The meaning behind attachment: Exploring } \\
\text { camaraderie, cause and competency at a } \\
\text { charity sport event }\end{array}$ & Journal of Sport Management \\
\hline 2011 & $\begin{array}{l}\text { Filo K. } \\
\text { Funk D.C. } \\
\text { O'Brien D. }\end{array}$ & $\begin{array}{l}\text { Examining Motivation for Charity Sport } \\
\text { Event Participation: A Comparison of } \\
\text { Recreation-Based and Charity-Based Motives }\end{array}$ & Journal of Leisure Research \\
\hline 2013 & $\begin{array}{l}\text { Filo K. } \\
\text { Spence K. } \\
\text { Sparvero E. }\end{array}$ & $\begin{array}{l}\text { Exploring the Properties of Community } \\
\text { among Charity Sport Event Participations }\end{array}$ & Managing Leisure \\
\hline 2017 & $\begin{array}{l}\text { Mirehie M. } \\
\text { Buning R.J. } \\
\text { Gibson H.J. }\end{array}$ & $\begin{array}{l}\text { Participation Versus Nonparticipation in a } \\
\text { Charity Running Event }\end{array}$ & Event Management \\
\hline 2020 & $\begin{array}{l}\text { Won D. } \\
\text { Park M. } \\
\text { Turner B.A. }\end{array}$ & $\begin{array}{l}\text { Motivations for Participating in Health } \\
\text { Related Charity Sport Events' }\end{array}$ & Journal of Venue and Event Management \\
\hline 2020 & $\begin{array}{l}\text { Meeprom S. } \\
\text { Dansiri W. }\end{array}$ & $\begin{array}{l}\text { Understanding motives for attending charity } \\
\text { sport events in Thailand }\end{array}$ & $\begin{array}{l}\text { International Journal of Culture, Tourism } \\
\text { and Hospitality Research }\end{array}$ \\
\hline 2021 & $\begin{array}{l}\text { Gibson H.J. } \\
\text { Buning R.J. } \\
\text { Weinberg M. }\end{array}$ & $\begin{array}{l}\text { Social capital, enduring involvement and } \\
\text { charity motive among runners: Comparing } \\
\text { event and non-event participants }\end{array}$ & $\begin{array}{l}\text { Conference Paper: European Association for } \\
\text { Sport Management Annual Conference }\end{array}$ \\
\hline
\end{tabular}

The Authors conducted research during special philanthropic sports events. They analyzed marketing tools used there, as well as examined the motives for participating in a charity event, reasons for engaging in sport and social life for a good cause. Research results show that over the years, charity events have gained more and more social recognition.

In order for an event of a social nature to be accessible to the widest possible group of active audiences, it should concern relatively cheap and easily accessible sport- to start it, we only need appropriate clothing, a place to practice, and, in addition, simple skills. A sport available to anyone who wants to practice it on a regular basis. It is valuable when it has a positive effect not only on the physical condition of a person, but also on their mental health. For this reason, we seek disciplines that also serve as a way to relax after work or maintain good health [5]. One such example is running. Recreation in the form of jogging is considered to be part of a healthy lifestyle, which allows a person to maintain a proper condition without much effort [6]. A noticeable increase in interest in running is visible in the growing number of participants taking part in mass runs-usually long- or mediumdistance [7]. Currently, the participants of such events are not only professional runners, but also amateurs and people treating sports events as a form of entertainment accessible to all. For this reason, both very large events and smaller, local running competitions are organized around the world-enticing, for example, with their unusual, attractive location or purpose [8]. 
One of the examples of pro-social events may be charity runs, in which participants, apart from wanting to run a certain distance, support participation in a charity fundraising, promote its ideas, and encourage support. They are a 'living medium' of information about organized initiatives. In order to attract an increasing number of participants every year, the organizers of sports events try to keep the knowledge of the motives for participating in the event up-to-date [9]. It can be useful for organizers, for example, in developing effective strategies for involving more participants in events [10]. For example, a survey of the New York charity road race "Race for a Cure" over a distance of $5 \mathrm{~km}$, indicated groups in terms of motives that are divided into 'social butterflies', 'event junkies' or 'event activists', i.e., people focused on social interactions, active participation and competition, as well as activists supporting the event [11]. In addition to supporting a charitable goal, event participants also have many other motives to participate, such as the willingness to socialize [12], achieve sports success or improve their performance [13], lead a healthy lifestyle [14], experience mental and physical stimulation [15], commune with other participants [16], engage in a good cause [17], help those in need [18], and even have fun or pleasure [19]. In addition to supporting a charity goal, event participants also have many other motives to participate, such as the desire to become socially involved [20], achieve sports success or improve condition [13], pursue a healthy lifestyle life [14], experiencing mental and physical stimulation [15], communing with other participants [16], engaging in a good cause [17], helping others [18], and even having fun or pleasure [19]. Charitable sporting events also provide participants with additional meaning, for example in the form of psychological benefits [20]. These are studied to a different extent, now even in terms of the psychological coherence of the motivation of charitable sports events by using the social identity theory [21]. Importantly, the above groups of motivations are noticeable in both women and men $[22,23]$. On the one hand, the participants may have the satisfaction of overcoming their own limitations, on the other, they may have the awareness that they did a good deed and could contribute to helping others through their participation. Another impulse for a positive reception may be the good atmosphere of the event-inspiring, stimulating to be active and encouraging during the competition. In the case of such events, however, it usually stays in the background-because it's not the player's success or the place they have achieved, but the willingness to participate is the highest value. The issues discussed in the text correspond with R. Putnam's theory of social capital. The author of this theory defines "social capital" as features of social life-networks, norms, and trust that enable participants to act together more effectively to pursue shared objectives. The norms, networks, and trust link substantial sectors of the community and span underlying social cleavages to the extent that the social capital is of a "bridging". In that case, the enhanced cooperation is likely to serve broader interests and to be widely welcomed [24]. Charity running events can also be described from the perspective of generating social capital resources. Participation in charity events brings people together, stimulating their willingness to help. It gives a sense of community in achieving one goal. Systematic inquiry of Putnam showed that, for example, the quality of governance was determined by longstanding traditions of civic engagement (or its absence). He is said that things like voter turnout, newspaper readership, membership in choral societies and football clubs were the hallmarks of a successful region and there is no doubt the mechanisms through which civic engagement and social connectedness produce such results are multiple and complex $[24,25]$. But involvement in social life and charity is needed, and every idea to spread such activity is commendable. Lifestyle in this research is understood as a way of living of a person or group, including style (active, passive), attitudes and possessions. Lifestyle is the interests, opinions, behaviors, and behavioral orientations of an individual, group, or culture; it is a combination of determining intangible or tangible factors. Tangible factors relate specifically to demographic variables, i.e., an individual's demographic profile, whereas intangible factors concern the psychological aspects of an individual such as personal values, preferences, and outlooks [26]. We recognize an active lifestyle is impossible without physical activity. However, some people find it really hard to run 
marathons, play basketball, swim, etc. They feel like there is a need to go the extra mile and prove something to others. The benefits of a physically active lifestyle are well documented in the literature. Individuals who engage in recommended levels of physical activity have a decreased risk of cardiovascular disease, type II diabetes, and certain kinds of cancer, as well as improved mental health. Additionally, those who engage in a physically active lifestyle are likely to live longer than those who do not, and to report a higher quality of life as they age [27]. In addition to the role that physical education and sports should play in promoting physical activity and public health, there are other domains like mass sporting events organization or charity. Social development and education are areas in which physical education and sport have the potential to have a powerful influence on people's development and their overall well-being.

In Poland, there was a significant increase in the organization of mass running events in 2013. For example, in 2003, 518 running events were organized, whereas in 2013 there were 2700 such events throughout the country [28]. In the 12 largest running events in Poland, the number of participants increased sixfold during a three-year period (20112013) [29]. Almost one-third of them have charitable character. Organizers try to find the theme of the sporting event to help those in need. As the years go by, charity running donations gain more and more social recognition [30,31]. Due to their global reputation and success, they have also found their place in Poland. An ideal example is the Wings for Life World Run organized in Poznan-as one of 33 cities in the world-the proceeds of which are allocated to research on spinal cord injuries. Its unusual formula with a moving finish in the form of a catcher car is so interesting that the number of runners in the capital of Wielkopolska has doubled over the last three years. In 2016, less than 4000 runners participated in the Poznan run, and in 2019 the number of participants was around 8000 [32]. An equally interesting run is the Warsaw Half Marathon, organized by Powszechny Zakład Ubezpieczeń (a polish publicly traded insurance company) for several years, during which the charity initiative 'Share a kilometer' is held. Its participants are most often actors, athletes or journalists, whose task is to run the longest possible distance on various training devices - which is then converted into a specific amount $(1 \mathrm{~km}=$ PLN 10) allocated to various charities. For example, in 2015 the money was transferred to the Committee for the Protection of Children's Rights [33] (Committee for the Protection of Children's Rights, 2015). Private individuals or entities established solely for the purpose of organizing charity events more and more often appear on Polish roads. An interesting initiative was the race by Paweł Meja, who in 2018 set the Polish Guinness Record in the 24-h barefoot race. He ran for charity for Artur Rosa-an eight-year-old boy from Tczew who suffers from encephalopathy [34]. Among the numerous events with a similar mission, there is also the Santa Claus Run organized in Poznan-the main message of which is to promote physical activity and a healthy lifestyle, but an equally important factor is the desire to unite runners to help children on a day when a smile on their face does not should disappear-on the day of Santa Claus, celebrated on December 6, when children receive gifts. The organizer of the 6th Santa Claus Run in Poznan, held in 2019, as in previous years, decided to allocate a part of the entry fee from each participant to the renovation of rooms in the Orphanage in Wagrowiec. In addition, in the competition office, there was a collection of sweets for the pupils from the facility [35].

\section{Aims of the Study}

The main goal of the study was to recognize the relationship between the lifestyles of men and women in the context of participation in a charity running event, to evaluate the differences between them. The specific goal was to discern the motives to take part in such kind of an event.

We wanted to find out what influence the participation in a charity run has on the respondents, both those leading an active and passive lifestyle. That is why we asked the following research questions where the first corresponds to the main purpose of the study and the second to the specific purpose of the research: 
1. Has participation in a sports and charity event encouraged the respondents to continue an active lifestyle (the main goal)?

2. Did the participants take part in the event because of their willingness to take up physical activity and participate in sports competitions, or maybe because of the willingness to help and contribute to a charity fundraiser (the specific goal)?

\section{Materials and Methods}

\subsection{Design and Participants}

The authors decided to conduct the research by the diagnostic survey method, using the standardized interview technique, during the 6th Santa Claus Run organized in Poznan on the day of Santa Claus, celebrated on December 6, 2019. The participants had to cover a distance of $10 \mathrm{~km}$ (adults) or $4.3 \mathrm{~km}$ (children) running or $4.3 \mathrm{~km}$ with the Nordic walking march. The main message of the event was to promote physical activity and a healthy lifestyle. However, the Santa Claus Run also aimed to unite the runners to help children on such an important day as December 6, the day Santa Claus brings gifts in Poland. Therefore, as in previous years, the organizer of the run decided to allocate part of the starting fee to the selected orphanage.

The sample size was determined on the basis of information from the organizers about the expected number of participants in the event. The authors of the study assumed that the sample was selected in a way that ensured the good representativeness of the obtained results. A total of 202 participants took part in the run, so the respondents constitute $67.3 \%$ of the entire group of runners. We treated the Santa Claus Run in Poznan, which has been taking place for several years, as a case study. A sample of 136 runners, 49 male respondents and 87 female respondents, participated in the event voluntarily and completed a questionnaire. We believe that this exhaustive test allowed us to obtain satisfactory results. The socio-demographic characteristics of respondents are presented below (Table 2).

Table 2. Socio-demographic characteristics of respondents.

\begin{tabular}{|c|c|c|c|c|c|c|c|c|c|c|}
\hline \multirow{4}{*}{$\begin{array}{l}\text { Socio-Demographic } \\
\text { Characteristics }\end{array}$} & \multirow{2}{*}{\multicolumn{4}{|c|}{$\begin{array}{c}\text { Active } \\
\text { Male/Female }\end{array}$}} & \multirow{2}{*}{\multicolumn{4}{|c|}{$\begin{array}{c}\begin{array}{c}\text { Passive } \\
\text { Male/Female }\end{array} \\
\mathrm{N}=18\end{array}$}} & \multirow{2}{*}{\multicolumn{2}{|c|}{ All }} \\
\hline & & & & & & & & & & \\
\hline & $\mathbf{M}$ & $\%$ & $\mathbf{F}$ & $\%$ & $\mathbf{M}$ & $\%$ & $\mathbf{F}$ & $\%$ & $\mathbf{N}$ & $\%$ \\
\hline & 45 & 38.13 & 73 & 61.87 & 4 & 22.22 & 14 & 77.78 & 136 & 100 \\
\hline \multicolumn{11}{|l|}{ Age } \\
\hline$<18$ & 4 & 3.39 & 4 & 3.39 & 1 & 5.55 & 1 & 5.55 & 10 & 7.35 \\
\hline $19-30$ & 9 & 7.63 & 25 & 21.19 & 1 & 5.55 & 3 & 16.66 & 38 & 27.94 \\
\hline $31-40$ & 19 & 16.1 & 25 & 21.19 & 1 & 5.55 & 5 & 27.77 & 50 & 36.76 \\
\hline $41-50$ & 8 & 6.78 & 16 & 13.56 & 2 & 11.11 & 3 & 16.66 & 29 & 21.32 \\
\hline$>51$ & 5 & 4.24 & 3 & 2.54 & 0 & 0.0 & 1 & 5.55 & 9 & 6.61 \\
\hline \multicolumn{11}{|l|}{ Education Level } \\
\hline Primary education & 3 & 2.54 & 4 & 3.39 & 1 & 5.55 & 1 & 5.55 & 9 & 6.61 \\
\hline Vocational education & 6 & 5.08 & 1 & 0.85 & 0 & 0.0 & 1 & 5.55 & 8 & 5.88 \\
\hline Secondary education & 16 & 13.56 & 28 & 23.72 & 2 & 11.11 & 5 & 27.77 & 51 & 37.5 \\
\hline Incomplete higher education & 5 & 4.24 & 5 & 4.24 & 1 & 5.55 & 1 & 5.55 & 12 & 8.82 \\
\hline Completed higher education & 15 & 12.71 & 35 & 29.66 & 1 & 5.55 & 5 & 27.77 & 56 & 41.17 \\
\hline \multicolumn{11}{|l|}{ Employment Status } \\
\hline School pupil (<18 years) & 4 & 3.39 & 4 & 3.39 & 2 & 11.11 & 2 & 11.11 & 12 & 8.82 \\
\hline University student & 1 & 0.85 & 8 & 6.78 & 2 & 11.11 & 0 & 0.0 & 11 & 8.08 \\
\hline Professionally active & 40 & 33.89 & 58 & 49.15 & 2 & 11.11 & 9 & 50.0 & 109 & 80.15 \\
\hline Unemployed & 0 & 0 & 2 & 1.69 & 0 & 0.0 & 0 & 0.0 & 2 & 1.47 \\
\hline Pensioner & 0 & 0 & 1 & 0.85 & 1 & 5.55 & 0 & 0.0 & 2 & 1.47 \\
\hline
\end{tabular}


Table 2. Cont.

\begin{tabular}{|c|c|c|c|c|c|c|c|c|c|c|}
\hline \multirow{4}{*}{$\begin{array}{l}\text { Socio-Demographic } \\
\text { Characteristics }\end{array}$} & \multirow{2}{*}{\multicolumn{4}{|c|}{$\begin{array}{c}\begin{array}{c}\text { Active } \\
\text { Male/Female }\end{array} \\
\mathrm{N}=\mathbf{1 1 8}\end{array}$}} & \multirow{2}{*}{\multicolumn{4}{|c|}{$\begin{array}{c}\begin{array}{c}\text { Passive } \\
\text { Male/Female }\end{array} \\
\mathrm{N}=18 \\
\end{array}$}} & \multirow{2}{*}{\multicolumn{2}{|c|}{ All }} \\
\hline & & & & & & & & & & \\
\hline & $\mathbf{M}$ & $\%$ & $\mathbf{F}$ & $\%$ & $\mathbf{M}$ & $\%$ & $\mathbf{F}$ & $\%$ & $\mathbf{N}$ & $\%$ \\
\hline & 45 & 38.13 & 73 & 61.87 & 4 & 22.22 & 14 & 77.78 & 136 & 100 \\
\hline \multicolumn{11}{|l|}{ Place of Residence } \\
\hline $\begin{array}{c}\text { City with over } 500,000 \\
\text { inhabitants }\end{array}$ & 16 & 13.56 & 20 & 16.95 & 3 & 16.66 & 2 & 11.11 & 41 & 34.5 \\
\hline $\begin{array}{l}\text { City with } 100,000-500,000 \\
\text { inhabitants }\end{array}$ & 1 & 0.85 & 8 & 6.78 & 1 & 5.55 & 1 & 5.55 & 11 & 8.08 \\
\hline $\begin{array}{c}\text { City with } 10,000-100,000 \\
\text { inhabitants }\end{array}$ & 8 & 6.78 & 19 & 16.1 & 0 & 0.0 & 4 & 22.22 & 31 & 22.79 \\
\hline $\begin{array}{l}\text { City with up to } 10,000 \\
\text { inhabitants }\end{array}$ & 6 & 5.08 & 4 & 3.39 & 0 & 0.0 & 1 & 5.55 & 11 & 8.08 \\
\hline Village & 14 & 11.86 & 22 & 18.64 & 1 & 5.55 & 5 & 27.77 & 42 & 30.88 \\
\hline
\end{tabular}

Socio-demographic characteristics in both groups of respondents (men and women) were similar. Among the surveyed participants, people with higher education constituted the vast majority. A greater percentage of them were professionally active.

\subsection{Instruments and Procedure}

A self-constructed questionnaire used for the study was divided into 3 parts, where the first allowed to obtain socio-demographic data (Table 2). The second part aimed at people with an active lifestyle. The third aimed at people leading a passive lifestyle. The questions concerned the motivation to participate in charity runs and their impact on lifestyle changes (7-point Likert scale). The research instrument was validated before the examined event-during the 5th Santa Claus Run organized in Poznan a year before the main research.

When determining the number of respondents, information from the organizers on the expected number of participants in the event was used to make the sample selection in a way that ensured the best possible representativeness of the results obtained. The scheme of simple random sampling without replacement was used. In calculations, the formula for sample size for finite population was used. An assumption was made that the maximum error of estimate (e) at 95\% confidence level should not exceed $4 \%$. Descriptive statistics (percentages, means, medians and standard deviations) were calculated and the nonparametric Mann-Whitney U test was used. Mann-Whitney U test was adopted due to the failure to meet the assumptions regarding the normality of the distribution of features-which was verified with Shapiro-Wilk's tests. Statistical significance was set at $p<0.05$. All statistical analyses were conducted using Statistica Software 10.0 [36].

\section{Results}

Table 3 shows the results of the research conducted among active participants, where:

Table 3. The impact of the charity event on the active participants and their motivation for participation.

\begin{tabular}{cccccc}
\hline Active & Mean & Median & Minimum & Maximum & $\begin{array}{c}\text { Standard } \\
\text { Deviation }\end{array}$ \\
\hline 1.A & 5.205 & 6.00 & 2 & 7.00 & 2.306 \\
\hline 2.A & 5.652 & 6.00 & 1.00 & 7.00 & 1.428 \\
\hline 3.A & 5.898 & 7.00 & 1.00 & 7.00 & 1.451 \\
\hline
\end{tabular}


1.A. I lead an active lifestyle and participation in today's sports and charity event encouraged me to continue an active lifestyle;

2.A. I took part in today's event because I wanted to take up physical activity and participate in sports competitions;

3.A. I took part in today's event because I wanted to help.

The results showed that people leading an active lifestyle were encouraged to continue their lifestyle at an average level of 5.2. They took part in the event because of their willingness to take up physical activity and participate in sports competition at an average level of 6.5, and because of their willingness to help at a level of 5.9.

Table 4 shows the results of the research conducted among passive participants, where:

Table 4. The impact of the charity event on the passive participants and their motivation for participation.

\begin{tabular}{cccccc}
\hline Passive & Mean & Median & Minimum & Maximum & $\begin{array}{c}\text { Standard } \\
\text { Deviation }\end{array}$ \\
\hline 1.B & 4.555 & 4.00 & 3.00 & 7.00 & 1.300 \\
\hline 2.B & 5.111 & 5.00 & 3.00 & 7.00 & 1.242 \\
\hline 3.B & 5.277 & 6.00 & 1.00 & 7.00 & 1.789 \\
\hline
\end{tabular}

1.B. I lead a passive lifestyle and participation in today's sports and charity event encouraged me to continue an active lifestyle;

2.B. I took part in today's event because I wanted to take up physical activity and participate in sports competitions;

3.B. I took part in today's event because I wanted to help.

The results showed that people leading a passive lifestyle were encouraged to continue their lifestyle at an average level of 4.5. They took part in the event because of their willingness to take up physical activity and participate in sports competition at an average level of 5.1 and because of their willingness to help at a level of 5.2.

The next stage of the research procedure is presented in Table 4 . In order to verify whether the gender of the respondent among people declaring an active lifestyle had an impact on their willingness to continue such a lifestyle after participating in the event, the non-parametric Mann-Whitney U test was carried out (I.a).

$$
\mathrm{U}\left(\mathrm{N}_{\text {women }}=73, \mathrm{~N}_{\text {men }}=45\right)=1397.50, z=-1.44, p=0.15 .
$$

The result of the analysis shows that there are no significant differences between women $(\mathrm{Mdn}=6.00)$ and $\operatorname{men}(\mathrm{Mdn}=6.00)$.

In order to verify whether the respondent's gender influenced their willingness to participate in the event due to the willingness to take up physical activity or participate in sports competition, the non-parametric Mann-Whitney U test was performed (II.a). Mann-Whitney $U$ test was adopted due to the failure to meet the assumptions regarding the normality of the distribution of features - which was verified with Shapiro-Wilk's tests.

$$
\mathrm{U}\left(\mathrm{N}_{\text {women }}=87, \mathrm{~N}_{\text {men }}=49\right)=1871.00, z=-1.22, p=0.22 \text {. }
$$

The result of the analysis shows that there are no significant differences between women $(\mathrm{Mdn}=6.00)$ and men $(\mathrm{Mdn}=6.00)$.

In order to verify whether the respondent's gender influenced their willingness to participate in the event due to the willingness to help, the non-parametric Mann-Whitney $\mathrm{U}$ test was performed. The result of the analysis shows significant differences between women and men (III.a).

$$
\mathrm{U}\left(\mathrm{N}_{\text {women }}=87, \mathrm{~N}_{\text {men }}=49\right)=1534.50, z=-2.89, p<0.01 .
$$


Women ( $\mathrm{Mdn}=7.00)$ showed a significantly higher level of willingness to participate in the event than men $(\mathrm{Mdn}=6.00)$ due to their willingness to help.

In order to verify whether the gender of the respondent among people declaring a passive lifestyle had an impact on their level of willingness to start an active lifestyle after participating in the event, the non-parametric Mann-Whitney U test was carried out (IV.a).

$$
\mathrm{U}\left(\mathrm{N}_{\text {women }}=14, \mathrm{~N}_{\text {men }}=4\right)=19.50, z=-0.97, p=0.33 \text {. }
$$

The result of the analysis indicates no significant differences between women $(\mathrm{Mdn}=4.00)$ and $\operatorname{men}(\mathrm{Mdn}=4.50)$.

In order to verify whether the declared lifestyle of the respondent (active/passive) had an impact on his or her level of willingness to participate in the event due to the willingness to take up physical activity or participate in sports competition, the non-parametric MannWhitney U test was carried out (Table 5).

$$
(\mathrm{Mdn}=5.00), \mathrm{U}\left(\mathrm{N}_{\text {active }}=118, \mathrm{~N}_{\text {passive }}=18\right)=772.00, z=-1.93, p=0.054 .
$$

\begin{tabular}{|c|c|c|c|c|c|c|c|}
\hline \multirow{2}{*}{$\begin{array}{c}\text { The Studied } \\
\text { Dependence (Sex) }\end{array}$} & \multicolumn{4}{|c|}{ Sample Size } & \multirow{2}{*}{$\begin{array}{c}\text { U Mann } \\
\text { Whitney's Test }\end{array}$} & \multirow{2}{*}{$z$} & \multirow{2}{*}{$p$} \\
\hline & Male & Median & Female & Median & & & \\
\hline I.a & 45 & 6.00 & 73 & 6.00 & 1397.50 & 1.44 & 0.15 \\
\hline II.a. & 49 & 6.00 & 87 & 6.00 & 1871.00 & -1.22 & 0.22 \\
\hline III.a & 49 & 6.00 & 87 & 7.00 & 1534.50 & -2.89 & $<0.01$ * \\
\hline IV.a & 4 & 4.50 & 14 & 4.00 & 19.50 & -0.97 & 0.33 \\
\hline
\end{tabular}

Table 5. Gender and related differences among the respondents.

The result of the analysis shows that there are no significant differences between active people $(\mathrm{Mdn}=6.00)$ and people with a passive lifestyle.

In order to verify whether the declared lifestyle of the respondent (active/passive) had an impact on their level of willingness to participate in the event due to the willingness to help, the non-parametric Mann-Whitney U test was carried out (Table 6.).

$$
\mathrm{U}\left(\mathrm{N}_{\text {active }}=118, \mathrm{~N}_{\text {passive }}=18\right)=843.00, z=-1.50, p=0.13 \text {. }
$$

\begin{tabular}{|c|c|c|c|c|c|c|c|}
\hline \multirow{2}{*}{$\begin{array}{l}\text { The Studied Dependence } \\
\text { (Active/Passive) }\end{array}$} & \multicolumn{4}{|c|}{ Sample Size } & \multirow{2}{*}{$\begin{array}{c}\text { Mann-Whitney } \\
\text { U Test }\end{array}$} & \multirow{2}{*}{$z$} & \multirow{2}{*}{$p$} \\
\hline & Active & Median & Passive & Median & & & \\
\hline I.b. & 118 & 6.00 & 18 & 5.00 & 772.00 & -1.93 & 0.054 \\
\hline II.b & 118 & 7.00 & 18 & 6.00 & 843.00 & -1.50 & 0.13 \\
\hline
\end{tabular}

Table 6. Style of living (active/passive) and related differences among the respondents.

The result of the analysis shows that there are no significant differences between active people $(\mathrm{Mdn}=7.00)$ and people with a passive lifestyle $(\mathrm{Mdn}=6.00)$.

\section{Discussion \& Conclusions}

The main goal of the study was to identify the relationship between the lifestyle of men and women in the context of participation in a charity running event, to evaluate the differences between them. The specific goal was to discern the motives to take part in such an event. The authors conducted the research by the diagnostic survey method, using the standardized interview technique during the sixth Santa Claus Run organized in 
Poznan. Descriptive statistics (percentages, means, medians and standard deviations) were calculated and the nonparametric Mann-Whitney U test was used.

Charity runs mean that participants taking part in this type of venture, apart from taking part, express their willingness and support in participating in a charity fundraising event, and all collected funds ultimately go to the account of a given foundation or a predetermined goal. Hosting sport events to raise money for charitable causes has become pervasive, yet we know little about why individuals choose to participate or not [37]. According to Chalip, community events, such as participatory sports events, may encourage a sense of community, bringing diverse groups of people together [38]. The results of Gibson and co-authors' research shows that runners with high social ties and those higher in social capital participated more regularly in charity-related events. Linking non-mega event social benefits to charity sports lines of research may offer some insights [39]. The study of Mirehie, Buning and Gibson examined the differences between participants and nonparticipants of a hallmark small-scale charity running event. The findings revealed that event participants and nonparticipants are very similar in terms of their running participation patterns [37].

For many years, fundraising for charity and good causes on the occasion of various running events has been very popular around the world [40]. In recent years, an increase in such events in Poland can also be observed, with the Santa Claus Run being one of the examples. Participants are satisfied with the effort put in, or with overcoming their own limitations. Additionally, satisfaction comes from knowing that in this way, they could help other people. When planning our study, we assumed that runners compete in charity runs out of the pure desire to do something good. We also decided that charity running is associated with a huge impact on the people around us, whom runners very often inspire to further action. Charity runs are always accompanied by a great atmosphere, and the competition, falling to the background, takes on a different, more beautiful dimension. This is why we decided to check what influence the participation in a charity run has on the respondents, in both those leading an active and passive lifestyle. To achieve that, we asked the respondents the following two questions. Firstly, has participation in a sports and charity event encouraged the respondents to continue an active lifestyle? Secondly, did the participants take part in the event because of their willingness to take up physical activity and participate in sports competitions, or maybe because of the willingness to help and contribute to a charity fundraiser?

The socio-demographic characteristics in both groups of respondents (men and women) were similar. The majority of runners were young, well-educated and professionally active. Among the surveyed men $(n=49)$, most were aged between 31 and 40 $(40.81 \%)$, then between 19 and $30(20.4 \%)$. Among men, people with secondary education constituted the vast majority (36.73\%), and $32.65 \%$ possessed higher education. A greater percentage of them $(85.71 \%)$ were professionally active. Most of the women (30) were aged $31-40(34.48 \%)$ and $29-30(32.18 \%)$. Among the surveyed women, 40 had completed higher education level (45.97\%), 37.93\% had secondary education. The employment status defined by the female respondents was very good, because over $77 \%$ (67) of women participants were professionally active.

The most important result, and the only statistically significant difference in the conducted studies, was the indication that women have more empathy and participate more often than men in a charity run to help. Previous studies on the differences in the level of empathy in women and men have shown that women are, by nature, more sensitive and understanding. They are also able to adopt the perspective of another person more often [41]. It is therefore consistent with the results obtained, which indicate the same tendency among the study participants. Silani et al. [42] showed that different kinds of stressful situations work differently depending on gender. Women become more vulnerable while seeking external support and show a greater need to belong [43]. Women react here by adopting an attitude consistent with the expectations of people from whom they want to gain recognition [44]. Men, on the other hand, are characterized by greater egocentrism, 
which means that in such situations, they show a lower level of empathy towards others. Here, too, there can be found a direct reference to the results obtained in the course of our own research, which showed exactly the same relationship. It seems that both behavior patterns have specific adaptation roles.

The results of the conducted research showed that men with an active lifestyle and regular runners did not consider participation in a charity run as significant. It is known that the overriding goal was to help, but participation in the race did not affect the respondents' lifestyle. In the case of people who declared a passive lifestyle, they will not change their attitude and do not encourage physical activity.

In this way, the results are aligned with some strategic changes related with sustainable adaptive sport opportunities, considering the sequence of activities and reflecting the sociocultural context [45].

Author Contributions: Conceptualization, E.M.-M.; methodology, E.M.-M.; software, J.P.; validation, J.P.; formal analysis, J.P.; investigation, M.M.; resources, J.P., N.A., M.R., E.M.-M.; data curation, J.P.; writing-original draft preparation, J.P. and M.R.; writing—review and editing, J.P. and N.A.; visualization, J.P. and M.R.; supervision, J.P.; project administration, J.P.; funding acquisition, N.A. All authors have read and agreed to the published version of the manuscript.

Funding: This research is financed by national funds through FCT-Foundation for Science and Technology, IP, within the scope of the reference project UIDB/04470/2020.

Conflicts of Interest: The authors declare no conflict of interest.

\section{References}

1. Won, D.; Park, M.; Turner, B.A. Motivations for Participating in Health Related Charity Sport Events. J. Venue Event Manag. 2010, $1,17-44$.

2. Filo, K.; Funk, D.C.; O’Brien, D. Examining Motivation for Charity Sport Event Participation: A Comparison of Recrea-tion-Based and Charity-Based Motives. J. Leis. Res. 2011, 43, 491-518. [CrossRef]

3. Lowell, S.; Silverman, L.; Taliento, L. Not-for-profit management: The gift that keeps on giving. McKinsey Q. $2001,1,147-155$.

4. Central Statistical Office. Działalność Stowarzyszeń i Podobnych Organizacji Społecznych, Fundacji, Społecznych Podmiotów Wyznaniowych oraz Samorzadu Gospodarczego i Zawodowego w 2018 r.-Wyniki Wstępne [Activities of Associations and Similar Social Organizations, Foundations, Social Religious Entities as well as Economic and Professional Self-Government in 2018-Preliminary Results].Informacje Ssygnalne, 23 grudnia 2019; Central Statistical Office: Warsaw, Poland, 2019.

5. Dobrosz, S. Prozdrowotne motywacje biegaczy-amatorów z województwa łódzkiego [Pro-health motivations of amateur runners from the Łódź Voivodeship]. Acta Univ. Lodz. Folia Sociol. 2019, 69, 107-118. [CrossRef]

6. Poczta, J.; Malchrowicz-Mośko, E. Modern Running Events in Sustainable Development-More than Just Taking Care of Health and Physical Condition (Poznan Half Marathon Case Study). Sustainability 2018, 10, 2145. [CrossRef]

7. Sierra, A.P.; Benetti, M.; Ghorayeb, N.; Sierra, C.; da Cunha Bastos, F.; Rocco Junior, A.; Kiss, M.A.P.D.M. Analysis of Participation and Performance in Half Marathon Runners. J. Sport Sci. 2015, 3, 96-104.

8. Parzonko, A.J.; Szuba, M. Uczestnictwo w imprezach biegowych jako forma rekreacji ruchowej [Participation in running events as a form of physical recreation]. Tur. Rozw. Reg. 2017, 7, 61-70.

9. Bennett, R.; Mousley, W.; Kitchin, P.; Ali-Choudhury, R. Motivations for participating in charity-affiliated sporting events. J. Cust. Behav. 2007, 6, 155-178. [CrossRef]

10. Kirkup, N.; Sutherland, M. Exploring the relationships between motivation, attachment and loyalty within sport event tourism. Curr. Issues Tour. 2017, 20, 7-14. [CrossRef]

11. Scott, A.; Solomon, P.J. The Marketing of Cause-Related Events: A Study of Participants as Consumers. J. Nonprofit Public Sect. Mark. 2003, 11, 43-66. [CrossRef]

12. Funk, D.C.; Ridinger, L.L.; Moorman, A.M. Exploring Origins of Involvement: Understanding the Relationship Between Consumer Motives and Involvement with Professional Sport Teams. Leis. Sci. 2004, 26, 35-61. [CrossRef]

13. Frederick, C.; Ryan, R. Differences in Motivation for Sport and Exercise and their Relationships with Participation and Mental Health. J. Sport Behav. 1993, 6, 125-145.

14. McDonald, M.; Milne, G.; Hong, J. Motivational Factors for Evaluating Sport Spectator and Participant Markets. Sport Mark. Q. 2002, 11, 100-113.

15. Recours, R.A.; Souville, M.; Griffet, J. Expressed Motives for Informal and Club/Association-based Sports Participation. J. Leis. Res. 2004, 36, 1-22. [CrossRef]

16. Kasser, T.; Ryan, R.M. Further Examining the American Dream: Differential Correlates of Intrinsic and Extrinsic Goals. Pers. Soc. Psychol. Bull. 1996, 22, 280-287. [CrossRef] 
17. Bennett, R.; Gabriel, H. Charity involvement and customer preference for charity brands. J. Brand Manag. 1999, 7, 49-66. [CrossRef]

18. Gladden, J.; Mahony, D.; Apostolopoulou, A. Toward a Better Understanding of College Athletic Donors: What are the Primary Motives? Sport Mark. Q. 2005, 14, 18-30.

19. Lindner, K.; Kerr, J. Predictability of Sport Participation Motivation from Metamotivational Dominances and Orientations. Personal. Individ. Differ. 2001, 30, 759-773. [CrossRef]

20. Webber, D. Understanding charity fundraising events. Int. J. Nonprofit Volunt. Sect. Mark. 2004, 9, 122-134. [CrossRef]

21. Meeprom, S.; Dansiri, W. Understanding motives for attending charity sport events in Thailand. Int. J. Cult. Tour. Hosp. Res. 2020, 15, 26-42. [CrossRef]

22. Malchrowicz-Mośko, E.; Rozmiarek, M. Why women run? Motivations for running in a half-marathon among female local runners and sport tourists. Olimp. J. Olymp. Stud. 2018, 2, 475-488. [CrossRef]

23. Malchrowicz-Mośko, E.; Poczta, J. Motivations for running in men: A comparative analysis of local runners and sports tourists. Turyzm 2019, 29, 69-79. [CrossRef]

24. Putnam, R.D. Tuning In, Tuning Out: The Strange Disappearance of Social Capital in America. Political Sci. Politics 1995, 28, 664-683. Available online: http:/ / www.jstor.org/stable/420517 (accessed on 1 March 2021). [CrossRef]

25. Putnam, R.D. Bowling Alone: America's Declining Social Capital. In Culture and Politics; Crothers, L., Lockhart, C., Eds.; Palgrave Macmillan: New York, NY, USA. [CrossRef]

26. Kahle, L.R.; Close, A.G. Consumer Behavior Knowledge for Effective Sports and Event Marketing; Routledge: New York, NY, USA, 2011; ISBN 978-0-415-87358-1.

27. Solmon, M.A. Physical Education, Sports, and Gender in Schools. Adv. Child Dev. Behav. 2014, 47, 117-150. [CrossRef] [PubMed]

28. Stempień, J.R. "Must be healthy, must be sporty"-Experiences of Poland and selected European countries. The case of popularity of running. In Promotion of Healthy Lifestyle in European Countries; Sawicki, B., Ed.; Katedra Turystyki i Rekreacji Uniwersytetu Przyrodniczego w Lublinie: Lublin, Poland, 2015; pp. 162-174.

29. Waśkowski, Z. Profil Polskiego Biegacza/Profile of a Polish Runner. Report. Available online: http://sm.nauka.ehost.pl/pdf/ Biegacze.pdf (accessed on 28 December 2015).

30. Filo, K.; Spence, K.; Sparvero, E. Exploring the properties of community among charity sport event participants. Manag. Leis. 2013, 18, 194-212. [CrossRef]

31. Filo, K.; Funk, D.C.; O'Brien, D. The Meaning Behind Attachment: Exploring Camaraderie, Cause, and Competency at a Charity Sport Event. J. Sport Manag. 2009, 23, 361-387. [CrossRef]

32. Szymczak, D. Wings for Life 2019 w Poznaniu za nami. Jedyny taki bieg na świecie: Bez mety, bez barier [Wings for Life 2019 in Poznań is behind us. The only such run in the world: No finish line, no barriers]. Gazeta Wyborcza 2019.

33. Komitet Ochrony Praw Dziecka. Podziel się kilometrem—biegasz i pomagasz dzieciom [Share the kilometer—run and help the children]. 2015. Available online: http://kopd.pl/aktualnosci/podziel-sie-kilometrem-biegasz-i-pomagasz-dzieciom/ (accessed on 12 December 2020).

34. Kwiatkowska, A. Paweł Mej przebiegł 93 kilometry boso w 24 godziny. Bieg zorganizowano dla chorego Arturka [Paweł Mej ran 93 kilometers barefoot in 24 hours. The run was organized for the sick Artur]. 2018. Available online: http:/ / polskabiega.sport. pl/polskabiega/7,105527,23374932,pawel-mej-przebiegl-92-kilometry-boso-w-24-godziny-bieg-zorganizowano.html (accessed on 28 December 2020).

35. Patroniak, R. Bieg Mikołajkowy 2019 nad Jeziorem Strzeszyńskim w Poznaniu. Startowałeś? Znajdź się na zdjęciach! [Santa Claus Run 2019 at Lake Strzeszyn in Poznań. Did you take off? Find yourself in the pictures!]. Głos Wielkop. 2019.

36. Statsoft Inc. Cracow, Poland. 2011. Available online: https://www.statsoft.pl/ (accessed on 28 December 2020).

37. Mirehie, M.; Buning, R.J.; Gibson, H.J. Participation Versus Nonparticipation in a Charity Running Event. Event Manag. 2017, 21, 639-652. [CrossRef]

38. Chalip, L. Towards Social Leverage of Sport Events. J. Sport Tour. 2006, 11, 109-127. [CrossRef]

39. Gibson, H.J.; Buning, R.J.; Weinberg, M. Social capital, enduring involvement and charity motive among runners: Comparing event and non-event participants. In Proceedings of the European Association for Sport Management Annual Conference, Istanbul, Turkey, 11-15 September 2013. Available online: https://www.researchgate.net/publication/281440121_ Social_capital_enduring_involvement_and_charity_motive_among_runners_Comparing_event_and_non-event_participants\# fullTextFileContent (accessed on 24 February 2021).

40. Hyde, M.K.; Dunn, J.; Wust, N.; Bax, C.; Chambers, S.K. Satisfaction, organizational commitment and future action in charity sport event volunteers. Int. J. Nonprofit Volunt. Sect. Mark. 2016, 21, 148-167. [CrossRef]

41. Wojciszke, B. Człowiek Wśród Ludzi. Zarys Psychologii Społecznej; Wydawnictwo Naukowe Scholar: Warsaw, Poland, 2004.

42. Silani, G.; Lamm, C.; Ruff, C.; Singer, T. Right supramarginal gyrus is crucial to overcome emotional egocentricity bias in social judgments. J. Neurosci. 2013, 33, 15466-15476. [CrossRef] [PubMed]

43. Williams, K.D. Ostracism. Annu. Rev. Psychol. 2007, 58, 425-452. [CrossRef] [PubMed]

44. Gamian-Wilk, M.; Szecówka-Nowak, M. Strategie radzenia sobie polskiej młodzieży ze szkół ponadpodstawowych z wykluczeniem społecznym. Educ. Psychol. 2020, 59, 25-40. [CrossRef]

45. Dickson, T.; Darcy, S.; Walker, C. A Case of Leveraging a Mega-Sport Event for a Sport Participation and Sport Tourism Legacy: A Prospective Longitudinal Case Study of Whistler Adaptive Sports. Sustainability 2021, 13, 170. [CrossRef] 